\title{
Soil moisture variation on the outlet area of devices dewatering forest roads in Beskid Sqqdecki
}

\author{
Janusz Gołab $b^{1} \bowtie$, Krzysztof Urban ${ }^{2}$, Elżbieta Badach ${ }^{3}$ \\ ${ }^{1}$ University of Agriculture in Krakow, Faculty of Forestry, Department of Forest Engineering, al. 29-listopada 46, \\ 31-425 Kraków, Poland, e-mail: rlgolab@cyf-kr.edu.pl \\ ${ }^{2}$ University of Agriculture in Krakow, The Experimental Forestry Unit in Krynica-Zdrój, Ludowa 10, \\ 33-380 Krynica-Zdrój, Poland \\ ${ }^{3}$ University of Agriculture in Krakow, Faculty of Agriculture and Economics, Department of Statistics and Econometrics, \\ al. Mickiewicza 21, 31-120 Kraków, Poland
}

\begin{abstract}
Water run-off - a natural part of water circulation in the natural environment - is a harmful and undesired phenomenon for humans. The most spectacular and most serious one is its erosive activity. In adverse conditions, such a runoff has high energy, it causes serious reshaping of a terrain and it destroys the natural environment and infrastructure. In the forest environment, a run-off process occurs basically on roads, skidding trails and in log storage sites, which are areas with soil cover properties changed by humans. The devices used for dehydrating a transport system direct water collected in the form of concentrated streams to a slope, which frequently causes serious linear damage or landslides. The objective of the tests carried out was to determine the spatial distribution of soil moisture on the area behind the outlet of devices dehydrating forest roads within the context of changes in selected soil properties affecting a risk of landslide formation.

The tests included four water drains dehydrating a forest slope road with a soil surface. In the area located behind the outlet, according to the model accepted, soil samples were collected for testing a current moisture value, determining grain composition and a hydraulic conductivity coefficient, calculated based on the simplified Hazen formula.

There were significant differences in the soil moisture means in the three-measurement series conducted; nevertheless, the highest moisture means were obtained after the lowest precipitation, and the lowest moisture means were obtained after the highest precipitation. It applies to all water drains observed, separately and collectively. Average moisture measures in all dehydrating facilities differed among one another, although in different sessions, this dependence was observed in various facility pairs. The statistical analysis did not demonstrate any significant differences in moisture in terms of the distance of moisture testing location from the road edge, or in locations with different distances from the water run-off line behind the outlet of dehydrating devices. Significant differences could be observed in the analysis of average moisture values in the soil layers.

Such an analysis result could be explained by a relatively low soil permeability and low slope gradient on the area examined. Usually, a few percent fluctuation in soil moisture, despite precipitation diversity, in combination with a high amount of granular soil structure, does not create conditions facilitating the formation of landslides.
\end{abstract}




\section{KeY WORDS}

area behind the outlet, dehydrating devices, landslide, mountain forests, slope roads, soil moisture

\section{INTRODUCTION}

Water run-off, as a constituent of water circulation in the natural environment, affects a circulation rate, which for humans, may evoke negative effects in the environment. First of all, it limits the amount of water available for widely understood consumption, since a high amount of precipitation (depending on the tightness of the catchment area cover) rapidly flows away from the catchment area beyond the reach of consumers (Wemple and Jones 2003; Gołąb 2012). It also contributes to the generation of high levels of streams and a related flood risk and erosive damage in stream beds. Erosive damage caused on the terrain surface before the run-off reaches the watercourse is also crucial. Most serious damage can be observed on agricultural areas and urban areas but also in forests. In forests, water run-

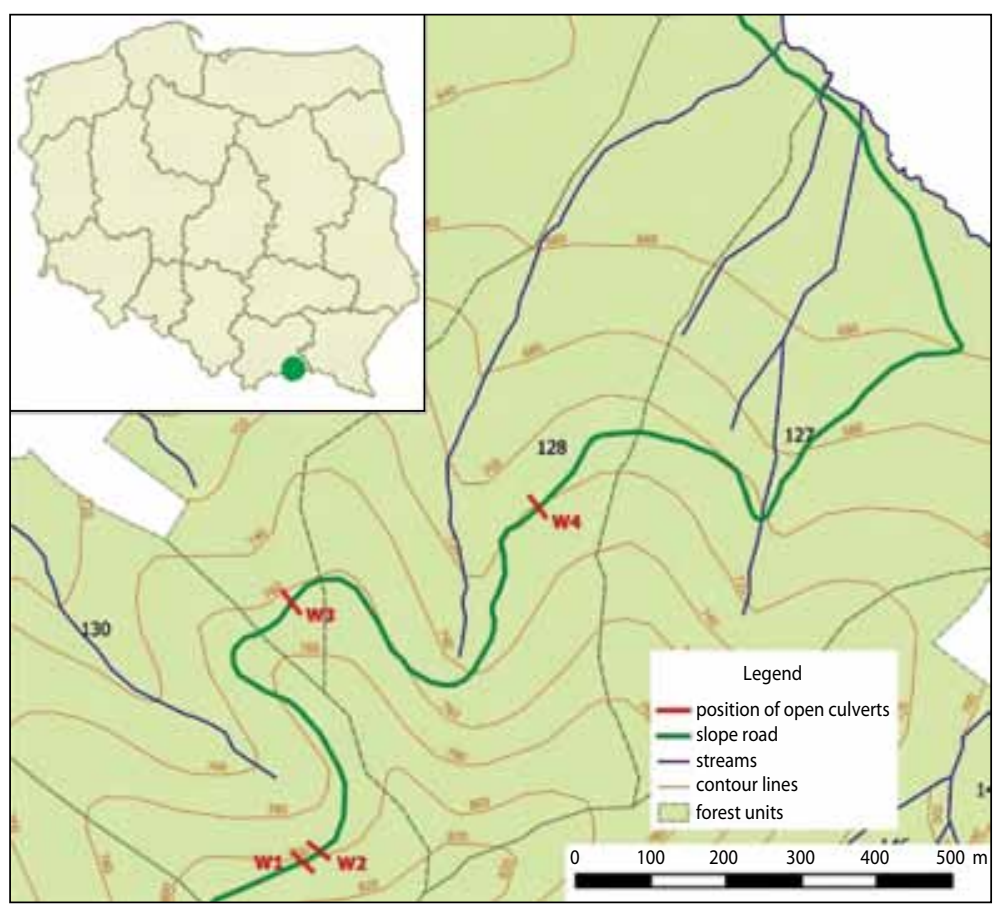

Figure 1. Network of forest roads and streams in Tylicz forestry with a marked slope road, with selected test facilities (based on Forest Numeric Map of Experimental Forestry Unit Krynica-Zdrój) off is mainly present on roads and in log storage sites, which are areas with changed specification of a soil surface (Gołąb et al. 2006; Gołąb 2011). It is connected with compaction and an increase in the load-bearing capacity of the plain, where heavy wheel traffic takes place (Burzyński and Rajsman 2006). Such a situation hinders or prevents water infiltration to the soil substratum (Gołąb and Kormanek 2013). Roads and log storage sites are built with longitudinal and cross gradients for efficient dehydration of surfaces and the water collected by dehydrating devices is discharged to the slope located below. The outflow of water along the slope behind the outlets of such devices is accumulated and it flows along the surface in the form of concentrated streams. After a shorter or longer distance, the run-off falls to the stream dehydrating a valley or it infiltrates to the soil in the localisation of a voluminous overburden or lower gradient. As a result of concentrated and rapid water run-off along the slope, deep erosive tunnels are frequently formed in the soil. Whereas, a high amount of water, after infiltration into the soil profile on a relatively small area, may form a landslide risk. Bardel (2012) notes (in the context of construction usefulness of soils in road building) that soils determined as poor in this category may be subject to landslides after building a road. In his opinion, it is particularly possible on areas where the water outflow from devices dehydrating roads is directed. In such a situation, soils change their moisture properties, which modifies their physical properties and increases mass, and which may lead to the loss of stability even on slopes with a low gradient. Similar conclusions are presented in the work of Zydroń and Cholewa (2014).

The objective of the tests carried out was to determine the spatial distribution of soil moisture on the area behind the outlet of devices dehydrating forest roads 
in the context of changes in the selected properties of soil, affecting a risk of landslide formation.

\section{Description of the area tested}

The tests were performed on the southern-east part of the Experimental Forestry Unit Krynica-Zdrój, in Tylicz forestry, near a forest road connecting TyliczMuszynka public road and Pusta stream valley (Fig. 1).

The selected facilities are located in the lower zone, at a height of about $720 \div 800 \mathrm{~m}$ a.s.l. In terms of geology, it is a flysch area consisting of sandstone and residual soil of Magura Nappe. Prevailing soil types are brown soils (over 95\%) with soil structure fragments. The most frequent type of settlement forest is fresh mountain forest (approx. 91\%). An average annual sum of precipitation is approx. $1000 \mathrm{~mm}$ (the highest $24 \mathrm{~h}$ sums are observed from June to August, the lowest ones from November to March). An average annual temperature reaches $+5.3^{\circ} \mathrm{C}$ (it ranges from $+3.8^{\circ} \mathrm{C}$ to $+6.8^{\circ} \mathrm{C}$ (Kondracki 2011; Characteristics of ExpFU 2015). On the measurement area, an afforestation rate is approx. $56 \%$, the following species of trees are dominant here: fir approx. $41 \%$, beech approx. 22\%, spruce approx. $18 \%$, pine approx. $11 \%$. A network of forest roads is well developed. Roads and streams from Tylicz forest- ry, including a road section where the tests are carried out, are presented in the map (Fig. 1).

\section{Methodology}

In order to achieve the objective of tests in the anticipated scope, soil moisture and grain composition was examined. These tests required collecting samples from soils in particular localisations at selected dehydrating facilities.

Four water drains were selected, dehydrating a slope road with a soil surface, which directed the water from surface to slope below the road. Based on the experiences from same type of tests conducted in Gorce National Park in the year 2014 (Gołąb et al. 2016), slopes with lower gradients were chosen. The facilities are marked as follows: W1, W2, W3 and W4. Their localisation on the slope road is presented on the map attached (Fig. 1).

Below (Tab. 1), there is a basic specification of the terrain, road and facilities chosen for the tests.Behind the outlet of each facility, there were places selected from where the soil samples were taken. In order to achieve the objective of the tests, which was to deter-

Table 1. Specification of test facilities

\begin{tabular}{|c|c|c|c|c|}
\hline \multirow{2}{*}{ Parameter/property } & \multicolumn{4}{|c|}{ Facility } \\
\hline & W1 & W2 & W3 & W4 \\
\hline Length & $4.40 \mathrm{~m}$ & $5.95 \mathrm{~m}$ & $6.05 \mathrm{~m}$ & $4.05 \mathrm{~m}$ \\
\hline Crossing angle of a facility axis with a roadway axis & $60^{\circ}$ & $60^{\circ}$ & $58^{\circ}$ & $88^{\circ}$ \\
\hline Material & wooden pole & sawn wood & sawn wood & wooden pole \\
\hline Inside diameter & $0.07 \mathrm{~m}$ & $0.10 \mathrm{~m}$ & $0.10 \mathrm{~m}$ & $0.08 \mathrm{~m}$ \\
\hline Outlet & not reinforced & not reinforced & not reinforced & not reinforced \\
\hline Facility longitudinal gradient & $4.5 \%$ & $7.0 \%$ & $8.5 \%$ & $5.0 \%$ \\
\hline Roadway longitudinal gradient & $7.5 \%$ & $5.5 \%$ & $11.0 \%$ & $9.5 \%$ \\
\hline Roadway cross gradient & $4.5 \%$ slope side & $5.0 \%$ slope side & $3.0 \%$ slope side & $4.0 \%$ slope side \\
\hline Average terrain gradient behind the outlet & $43.0 \%$ & $30.0 \%$ & $30.0 \%$ & $24.0 \%$ \\
\hline Roadway width & $2.70 \mathrm{~m}$ & $3.20 \mathrm{~m}$ & $2.30 \mathrm{~m}$ & $2.60 \mathrm{~m}$ \\
\hline Sideway width & $0.60 \mathrm{~m}$ & $0.50 \mathrm{~m}$ & $0.80 \mathrm{~m}$ & $0.40 \mathrm{~m}$ \\
\hline Surface of road & \multicolumn{4}{|c|}{ profiled soil } \\
\hline By-slope ditch width & - & $1.20 \mathrm{~m}$ & $1.10 \mathrm{~m}$ & - \\
\hline By-slope ditch depth & - & $0.35 \mathrm{~m}$ & $0.35 \mathrm{~m}$ & - \\
\hline
\end{tabular}

Source: author's measurement. 
mine the spatial distribution of soil moisture behind the outlets of dehydrating devices, it was decided to arrange the selected locations in the grid of $5 \times 5 \mathrm{~m}$, that is, measuring from the edge of the road sideway, along the slope, $5 \mathrm{~m}$ below there will be an agreed line ' $\mathrm{A}$ ' and $5 \mathrm{~m}$ below the line 'A' there will be line 'B'; near the water run-off line behind the outlet, there will be two lines on each side, roughly perpendicular to lines ' $\mathrm{A}$ ' and ' $\mathrm{B}$ ' and distant from themapproximately $5 \mathrm{~m}$, on the outside, two more lines (these lines are called 'positions'; symbols: ' 1 ', '2', '3', '4'); in such a grid, samples were collected from two depth levels: 'g' and 'd', where 'g' $=$ approximately $20 \mathrm{~cm}$ and ' $\mathrm{d}$ ' = approximately $60 \mathrm{~cm}$ (without an organic overburden).

The model presented above, including the corresponding numbering, is demonstrated in Figure 2. The model of localisations for soil sampling in Gorce tests for the year 2014 was also applied in this case (Gołą et al. 2016); nevertheless, one must note that the reversed numbering of 'positions' (in the tested area - view towards the road) applied in Experimental Forestry Unit compared to the tests performed in Gorce National Park in the year 2014. It results from attempting to preserve the same marking of 'positions' as in Gorce National
Park, namely: 'position 1' lies on the side of the highest vertical alignment ordinates, and 'item 4' on the side of the lowest vertical alignment ordinates.

Samples were taken by means of a stapedial soil drill with the diameter of approximately $6 \mathrm{~cm}$, which enables taking out a loosened soil mass from the outlet. Such a sample has a broken structure but it does not hinder the performance of complex analyses. Soil from respective depths was immediately placed in tight jars with the capacity of $0.5 \mathrm{dm}^{3}$. A bore hole was temporarily marked as a changed area and not suitable for subsequent appointment for sampling.

The following soil properties were determined based on the samples taken: gravimetric moisture (w192 tests in three measurement sessions with different weather conditions), grain composition (8 tests), reliable diameter $\left(d_{10}-\right.$ determined for 8 samples $)$, soil hydraulic conductivity coefficient ( $k$ - determined for 8 samples).

A current moisture value was determined by means of a model drying and weighing method, in accordance with the methodology described in norm (PN-ISO 11465:1999).

Grain composition was determined by the combination of following methods: sieve and laser method on

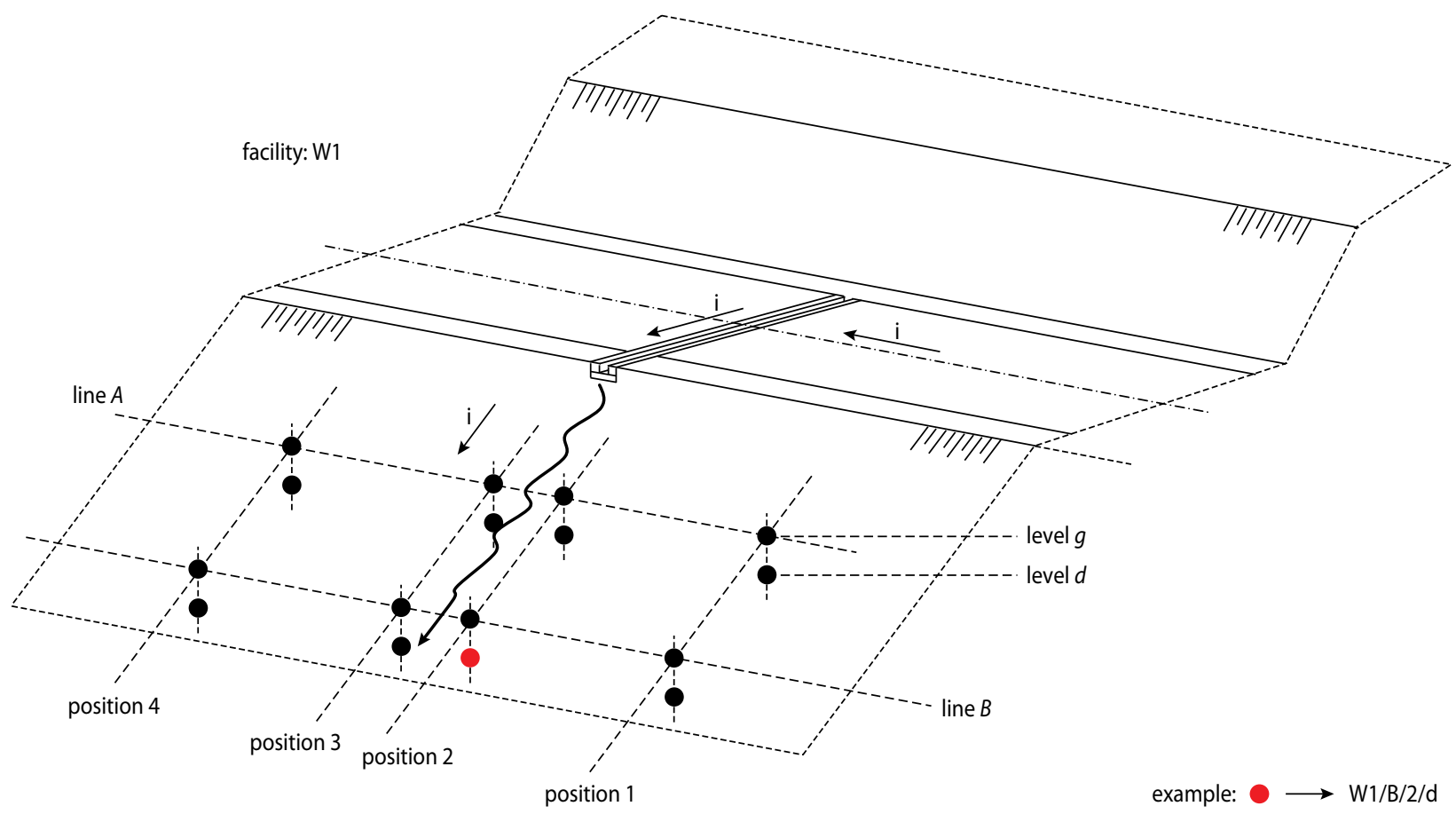

Figure 2. Model of localisations of soil sampling and numbering 
indicated samples (bottom level from samples in the line $\mathrm{B}$, in positions 2 and 3, near the drain line). The prepared samples were sieved through the set of sieves $0.01 \mathrm{~m}, 0.005 \mathrm{~mm}, 0.002 \mathrm{~mm}, 0.001 \mathrm{~mm}$, then small fractions $(<0.001 \mathrm{~mm})$ underwent a laser composition analysis.

A hydraulic conductivity coefficient, which describes the ease with which a fluid (usually water) can move through pore spaces or fractures, was determined based on the simplified Hazen formula (eqn. 1) (Twardowski and Drożdżak 2006), which makes use of a reliable diameter $\mathrm{d}_{10}$, read from the sample particle size curve. A reliable diameter $\mathrm{d}_{10}$ determines the size of soil particles at 10 percent smaller particles than the diameter in the sample.

$$
k_{10}=0.0116 \cdot d_{10}^{2}\left[m \cdot s^{-1}\right]
$$

where:

$k_{10}$ - hydraulic conductivity coefficient at water temperature of $10^{\circ} \mathrm{C}$,

$d_{10}$ - reliable diameter $[\mathrm{m}]$.

On this basis, making use of Stypuła classification (1977), a permeability degree of the soil tested was determined.

A sum of $24 \mathrm{H}$ precipitation from one $\left(\Sigma_{1}\right)$, two $\left(\Sigma_{2}\right)$ and three days $\left(\Sigma_{3}\right)$ preceding measurement sessions $\left(\mathrm{P}_{\mathrm{I}}, \mathrm{P}_{\mathrm{II}}, \mathrm{P}_{\mathrm{III}}\right)$ was provided as an additional description of conditions for the formation of run-off:

\begin{tabular}{|c|c|c|}
\hline $\begin{array}{c}\text { Session I } \\
(9 \text { VII 2015) }\end{array}$ & $\begin{array}{c}\text { Session II } \\
(27 \text { IX 2015) }\end{array}$ & $\begin{array}{c}\text { Session III } \\
(18 \text { X 2015) }\end{array}$ \\
\hline$\Sigma_{1} \mathrm{P}_{\mathrm{I}}=25.6 \mathrm{~mm}$ & $\Sigma_{1} \mathrm{P}_{\text {II }}=25.8 \mathrm{~mm}$ & $\Sigma_{1} \mathrm{P}_{\text {III }}=0.6 \mathrm{~mm}$ \\
\hline$\Sigma_{2} \mathrm{P}_{\mathrm{I}}=26.0 \mathrm{~mm}$ & $\Sigma_{2} \mathrm{P}_{\text {II }}=49.9 \mathrm{~mm}$ & $\Sigma_{2} \mathrm{P}_{\text {III }}=8.9 \mathrm{~mm}$ \\
\hline$\Sigma_{3} \mathrm{P}_{\mathrm{I}}=26.0 \mathrm{~mm}$ & $\Sigma_{3} \mathrm{P}_{\text {II }}=67.9 \mathrm{~mm}$ & $\Sigma_{3} \mathrm{P}_{\text {III }}=10.1 \mathrm{~mm}$ \\
\hline
\end{tabular}

Source: measurement data collected by SBF Mochnaczka Wyżna, provided by the Department of Forest Protection, Entomology and Forest Climatology of the University of Agriculture in Kraków.

\section{Measurement Results}

The complete set of results and their analysis was presented in the test report (Gołąb and Urban 2016) - only the most important results are cited here. The Table 2 presents soil moisture samples in respective measurement sessions.
Table 2. Soil samples moisture

\begin{tabular}{|c|c|c|c|c|c|c|c|}
\hline \multirow{2}{*}{$\begin{array}{l}\text { Sample } \\
\text { number }\end{array}$} & VII & 27 IX & $18 \mathrm{X}$ & \multirow{2}{*}{$\begin{array}{l}\text { Sample } \\
\text { number }\end{array}$} & $9 \mathrm{VII}$ & 27 IX & $18 X$ \\
\hline & \multicolumn{3}{|c|}{$[\%]$} & & \multicolumn{3}{|c|}{$[\%]$} \\
\hline $\mathrm{W} 1 / \mathrm{A} / 1 / \mathrm{g}$ & 37.72 & 25.47 & 33.43 & $\mathrm{~W} 3 / \mathrm{A} / 1 / \mathrm{g}$ & 17.56 & 12.74 & 22.67 \\
\hline $1 / \mathrm{d}$ & 7 & 22.00 & 26.5 & $1 / \mathrm{d}$ & 18.29 & 8.60 & 21.71 \\
\hline $\mathrm{W} 1 / \mathrm{A}$ & 1.46 & 27.55 & 47.86 & $\mathrm{~W} 3 / \mathrm{A} / 2 / \mathrm{g}$ & 35.49 & 21.02 & 46.68 \\
\hline & 5.10 & 21.06 & 32.55 & & 28.01 & 17.82 & 22.50 \\
\hline W1/ & .43 & 36.31 & 27.23 & $3 / \mathrm{g}$ & 3.96 & 20.28 & 13.27 \\
\hline $\mathrm{W} 1 / \mathrm{A}$ & 20.51 & 24.36 & 35.13 & $\mathrm{~N} 3 / \mathrm{A} / 3 / \mathrm{d}$ & 17.51 & 15.03 & 17.12 \\
\hline & 9.04 & 28.21 & 34.98 & & 17.67 & 15.12 & 18.70 \\
\hline $\mathrm{W} 1 / \mathrm{A}$ & .67 & 17.11 & 21.61 & $/ 4 / \mathrm{d}$ & 12.68 & 14.35 & 17.06 \\
\hline $\mathrm{W} 1 / \mathrm{l}$ & 0.51 & 24.63 & 28.09 & $3 / \mathrm{B} / 1 / \mathrm{g}$ & 28.59 & 26.06 & 26.88 \\
\hline $1 / \mathrm{d}$ & .06 & 15.03 & 20.21 & & 5.53 & 15.77 & 29.52 \\
\hline $\mathrm{W} 1 / \mathrm{B} / 2 / \mathrm{g}$ & 9.83 & 33.44 & 37.07 & $\mathrm{~W} 3 / \mathrm{B} / 2 / \mathrm{g}$ & 21.77 & 20.24 & 25.40 \\
\hline $\mathrm{W} 1 / \mathrm{l}$ & .85 & 16.88 & 18.70 & $/ 2 / \mathrm{d}$ & 18.60 & 21.96 & 19.28 \\
\hline & 6.03 & 9.76 & 34.31 & & 33.33 & 23.53 & 31.86 \\
\hline $\mathrm{W} 1 / \mathrm{l}$ & 5.27 & 13.09 & 22.80 & $3 / d$ & 16.52 & 17.90 & 22.65 \\
\hline $\mathrm{W} 1 / \mathrm{l}$ & 6.21 & 17.00 & 29.15 & $4 / g$ & 21.14 & 19.12 & 20.72 \\
\hline $\mathrm{W} 1 / \mathrm{H}$ & 2.17 & 4.36 & 22.06 & $4 / d$ & 3.78 & 12.62 & 16.25 \\
\hline $\mathrm{W} 2 / \mathrm{A}$ & 27.72 & 18.37 & 32.50 & $1 / \mathrm{g}$ & 8.35 & 14.35 & 14.78 \\
\hline $\mathrm{W} 2 / \mathrm{A}$ & 21.53 & 19.39 & 28.42 & $/ 1 / \mathrm{d}$ & 15.67 & 10.95 & 12.82 \\
\hline $\mathrm{W} 2 / \mathrm{A}$ & .35 & 9.99 & 47.49 & $/ 2 / \mathrm{g}$ & 13.67 & 18.06 & 26.06 \\
\hline$/ 2 / \mathrm{d}$ & 28.16 & 19.99 & 23.76 & $/ 2 / \mathrm{d}$ & 11.64 & 12.99 & 17.74 \\
\hline $\mathrm{W} 2 / \mathrm{A} / 3 / \mathrm{g}$ & 34.61 & 35.65 & 27.12 & $/ 3 / g$ & 30.16 & 26.70 & 35.68 \\
\hline$/ 3 / \mathrm{d}$ & 26.97 & 17.03 & 20.30 & $/ 3 / \mathrm{d}$ & 15.01 & 15.67 & 14.65 \\
\hline $2 / \mathrm{A} / 4 / \mathrm{g}$ & 39.61 & 37.84 & 37.16 & & 25.46 & 28.55 & 26.81 \\
\hline $\mathrm{W} 2 / \mathrm{A} / 4 / \mathrm{d}$ & 21.80 & 16.65 & 20.61 & $\mathrm{~W} 4 / \mathrm{A} / 4 / \mathrm{d}$ & 11.25 & 15.36 & 19.23 \\
\hline $\mathrm{W} 2 / \mathrm{B} / 1 / \mathrm{g}$ & 34.01 & 34.15 & 30.57 & $\mathrm{~W} 4 / \mathrm{B} / 1 / \mathrm{g}$ & 18.86 & 24.51 & 21.78 \\
\hline $\mathrm{W} 2 / \mathrm{B} / 1 / \mathrm{d}$ & 20.68 & 18.80 & 19.94 & W4/ & 14.30 & 14.42 & 14.90 \\
\hline $\mathrm{W} 2 / \mathrm{B} / 2 / \mathrm{g}$ & 32.59 & 36.78 & 35.82 & $\mathrm{~W} 4 / \mathrm{B} / 2 / \mathrm{g}$ & 23.04 & 21.58 & 25.92 \\
\hline $\mathrm{W} 2 / \mathrm{B} / 2 / \mathrm{d}$ & 18.08 & 19.73 & 19.61 & $\mathrm{~W} 4 / \mathrm{B} / 2 / \mathrm{d}$ & 14.39 & 12.16 & 17.72 \\
\hline $\mathrm{W} 2 / \mathrm{B} / 3 / \mathrm{g}$ & 28.92 & 29.38 & 32.32 & $\mathrm{~W} 4 / \mathrm{B} / 3 / \mathrm{g}$ & 26.08 & 17.11 & 29.69 \\
\hline $\mathrm{W} 2 / \mathrm{B} / 3 / \mathrm{d}$ & 25.53 & 23.22 & 22.52 & $\mathrm{~W} 4 / \mathrm{B} / 3 / \mathrm{d}$ & 17.63 & 9.68 & 20.98 \\
\hline $\mathrm{W} 2 / \mathrm{B} / 4 / \mathrm{g}$ & 34.31 & 27.14 & 26.63 & $\mathrm{~W} 4 / \mathrm{B} / 4 / \mathrm{g}$ & 18.94 & 13.92 & 23.63 \\
\hline $\mathrm{W} 2 / \mathrm{B} / 4 / \mathrm{d}$ & 20.68 & 19.55 & 17.25 & $\mathrm{~W} 4 / \mathrm{B} / 4 / \mathrm{d}$ & 14.95 & 9.97 & 16.45 \\
\hline
\end{tabular}


The soil samples were also used for determining a particle size, according to norm (PN-86/B-02480). Table 3 presents the data obtained.

With the use of particle size curves of the abovementioned soils (not presented herein) reliable diameters $d_{10}$ were determined for the selected soil samples
(Tab. 4) and hydraulic conductivity coefficients $k$ were calculated. Then, according to the average values of the said coefficients (for a facility), soils were classified according to water permeability based on the classification proposed by Stypuła (1977).

Table 3. Particle size of selected soil samples

\begin{tabular}{|c|c|c|c|c|c|c|c|c|c|}
\hline \multirow{3}{*}{ Fraction } & \multirow{3}{*}{$\begin{array}{l}\text { Range of } \\
\text { substitution } \\
\text { diameter } \\
{[\mathrm{mm}]}\end{array}$} & \multicolumn{8}{|c|}{ Sample number } \\
\hline & & $\mathrm{W} 1 / \mathrm{B} / 2 / \mathrm{d}$ & $\mathrm{W} 1 / \mathrm{B} / 3 / \mathrm{d}$ & $\mathrm{W} 2 / \mathrm{B} / 2 / \mathrm{d}$ & $\mathrm{W} 2 / \mathrm{B} / 3 / \mathrm{d}$ & $\mathrm{W} 3 / \mathrm{B} / 2 / \mathrm{d}$ & $\mathrm{W} 3 / \mathrm{B} / 3 / \mathrm{d}$ & $\mathrm{W} 4 / \mathrm{B} / 2 / \mathrm{d}$ & $\mathrm{W} 4 / \mathrm{B} / 3 / \mathrm{d}$ \\
\hline & & \multicolumn{8}{|c|}{$\begin{array}{c}\text { Mass fraction of substitution diameter range }[\mathrm{g}] \\
\text { Percentage of fraction }\end{array}$} \\
\hline \multirow{3}{*}{ Gravel } & $>5$ & 28.996 & 72.404 & 71.980 & 5.104 & 32.400 & 55.248 & 75.752 & 42.110 \\
\hline & & & & & & & & & \\
\hline & $5 \div 2$ & $\begin{array}{l}45.104 \\
14.22\end{array}$ & $\begin{array}{l}59.140 \\
17.71\end{array}$ & $\begin{array}{l}23.508 \\
11.53\end{array}$ & $\begin{array}{l}32.886 \\
12.59\end{array}$ & $\begin{array}{c}19.928 \\
6.88\end{array}$ & $\begin{array}{c}17.408 \\
5.75\end{array}$ & $\begin{array}{c}19.318 \\
5.22\end{array}$ & $\begin{array}{c}27.226 \\
6.91\end{array}$ \\
\hline \multirow{10}{*}{ Sand } & $2 \div 1$ & 31.748 & 30.186 & 23.576 & 42.722 & 27.092 & 26.816 & 27.628 & 33.700 \\
\hline & & & & & & & & & \\
\hline & $1 \div 05$ & 0.914 & 1.072 & 0.989 & 0.566 & 2.862 & 1.253 & 1.448 & 1.861 \\
\hline & $1 \div 0.5$ & 0.29 & 0.32 & 0.49 & 0.22 & 0.99 & 0.41 & 0.39 & 0.47 \\
\hline & & 0.471 & 0.552 & 0.510 & 0.566 & 1.555 & 1.211 & 42.698 & 19.823 \\
\hline & $0.5 \div 0.25$ & 0.15 & 0.17 & 0.25 & 0.22 & 0.54 & 0.40 & 11.53 & 5.03 \\
\hline & 025.01 & 3.885 & 2.559 & 0.499 & 0.425 & 43.858 & 35.512 & 67.185 & 85.081 \\
\hline & $0.25 \div 0.1$ & 1.23 & 0.77 & 0.24 & 0.16 & 15.14 & 11.74 & 18.15 & 21.59 \\
\hline & 01.005 & 68.676 & 54.668 & 15.357 & 8.054 & 37.533 & 36.218 & 20.057 & 26.335 \\
\hline & $0.1 \div 0.05$ & 21.65 & 16.37 & 7.53 & 3.08 & 12.96 & 11.97 & 5.42 & 6.68 \\
\hline \multirow{4}{*}{ Dust } & $005 \div 002$ & 29.718 & 24.477 & 9.239 & 10.650 & 16.797 & 15.335 & 10.828 & 15.338 \\
\hline & $0.03 \div 0.02$ & 9.37 & 7.33 & 4.53 & 4.08 & 5.80 & 5.07 & 2.92 & 3.89 \\
\hline & $00 ?$ & 96.188 & 78.121 & 52.147 & 140.685 & 93.626 & 100.282 & 90.441 & 119.808 \\
\hline & $0.02 \div 0.002$ & 30.33 & 23.39 & 25.58 & 53.85 & 32.32 & 33.14 & 24.43 & 30.41 \\
\hline \multirow{2}{*}{ Clay } & $<0002$ & 11.446 & 10.746 & 6.076 & 19.599 & 13.997 & 13.317 & 14.889 & 22.717 \\
\hline & $<0.002$ & 3.61 & 3.22 & 2.98 & 7.50 & 4.83 & 4.40 & 4.02 & 5.77 \\
\hline \multirow{2}{*}{\multicolumn{2}{|c|}{$\Sigma=$}} & 333.924 & 317.146 & 333.924 & 203.882 & 261.258 & 289.648 & 302.600 & 370.244 \\
\hline & & 100.00 & 100.00 & 100.00 & 100.00 & 100.00 & 100.00 & 100.00 & 100.00 \\
\hline Fractions & sand $=$ & 43.49 & 43.99 & 37.75 & 23.44 & 47.57 & 43.93 & 57.79 & 51.38 \\
\hline reduced & dust $=$ & 51.80 & 50.69 & 56.58 & 67.78 & 46.53 & 50.28 & 36.80 & 41.63 \\
\hline$[\%]$ & clay $=$ & 4.71 & 5.32 & 5.67 & 8.78 & 5.90 & 5.79 & 5.41 & 6.99 \\
\hline \multicolumn{2}{|c|}{$\begin{array}{l}\text { Grain composition } \\
\text { group } \\
\text { by PN-86/B-02480 } \\
\text { (on the base } \\
\text { of reduced fractions) }\end{array}$} & $\begin{array}{c}\text { sandy } \\
\text { dust }\end{array}$ & $\begin{array}{c}\text { sandy } \\
\text { dust }\end{array}$ & $\begin{array}{c}\text { sandy } \\
\text { dust }\end{array}$ & dust & $\begin{array}{c}\text { sandy } \\
\text { dust }\end{array}$ & $\begin{array}{c}\text { sandy } \\
\text { dust }\end{array}$ & $\begin{array}{c}\text { sandy } \\
\text { dust }\end{array}$ & $\begin{array}{l}\text { sandy } \\
\text { dust }\end{array}$ \\
\hline
\end{tabular}


Table 4. The values of a hydraulic conductivity coefficient determined based on the simplified Hazen formula

\begin{tabular}{|c|c|c|c|c|c|}
\hline \multirow{2}{*}{$\begin{array}{l}\text { Sample } \\
\text { number }\end{array}$} & \multirow{2}{*}{$\begin{array}{l}\text { Grain composition } \\
\text { group } \\
(\mathrm{PN}-86 / \mathrm{B}-02480)\end{array}$} & \multicolumn{3}{|c|}{ Hydraulic conductivity coefficient } & \multirow{2}{*}{$\begin{array}{l}\text { Classification } \\
\text { of soil water permeability } \\
\text { according to Stypuła (1977) }\end{array}$} \\
\hline & & $\begin{array}{c}\mathrm{d}_{10} \\
{[\mathrm{~mm}]}\end{array}$ & $k_{10}=0.0116 \cdot d_{10}^{2}\left[m \cdot s^{-1}\right]$ & $\begin{array}{c}K_{10 \text { avg }} \\
{\left[\mathrm{m}^{-1} \cdot \mathrm{s}^{-1}\right]}\end{array}$ & \\
\hline $\mathrm{W} 1 / \mathrm{B} / 2 / \mathrm{d}$ & sandy dust & 0.00110 & $1.40 \cdot 10^{-8}$ & \multirow{2}{*}{$1.54 \cdot 10^{-8}$} & \multirow{2}{*}{ practically non-permeable } \\
\hline $\mathrm{W} 1 / \mathrm{B} / 3 / \mathrm{d}$ & sandy dust & 0.00120 & $1.67 \cdot 10^{-8}$ & & \\
\hline $\mathrm{W} 2 / \mathrm{B} / 2 / \mathrm{d}$ & sandy dust & 0.00120 & $1.67 \cdot 10^{-8}$ & \multirow{2}{*}{$1.47 \cdot 10^{-8}$} & \multirow{2}{*}{ practically non-permeable } \\
\hline $\mathrm{W} 2 / \mathrm{B} / 3 / \mathrm{d}$ & dust & 0.00105 & $1.28 \cdot 10^{-8}$ & & \\
\hline $\mathrm{W} 3 / \mathrm{B} / 2 / \mathrm{d}$ & sandy dust & 0.00111 & $1.43 \cdot 10^{-8}$ & \multirow{2}{*}{$1.42 \cdot 10^{-8}$} & \multirow{2}{*}{ practically non-permeable } \\
\hline $\mathrm{W} 3 / \mathrm{B} / 3 / \mathrm{d}$ & sandy dust & 0.00110 & $1.40 \cdot 10^{-8}$ & & \\
\hline $\mathrm{W} 4 / \mathrm{B} / 2 / \mathrm{d}$ & sandy dust & 0.00110 & $1.40 \cdot 10^{-8}$ & \multirow{2}{*}{$1.34 \cdot 10^{-8}$} & \multirow{2}{*}{ practically non-permeable } \\
\hline $\mathrm{W} 4 / \mathrm{B} / 3 / \mathrm{d}$ & sandy dust & 0.00105 & $1.28 \cdot 10^{-8}$ & & \\
\hline
\end{tabular}

Symbols: $d_{10}$ - reliable diameter; $k_{10}$ - soil hydraulic conductivity coefficient (water temperature $10^{\circ} \mathrm{C}$ ).

\section{Analysis}

The graphic analysis of the spatial distribution of soil moisture was performed in vertical plains intersecting the terrain in the lines A and B, in position 1, 2, 3 and 4 and in the slope gradient plains (based on the accepted depths of soil sampling). Exemplary figures containing isometric lines, according to the calculated soil moisture values, are presented in Figure 3 and Figure 4. Graph axes are dimensioned in metres and the system of soil sample localisation, based on which an isoline course was interpolated, is adjusted to the rectangular system for simplification reasons.
A

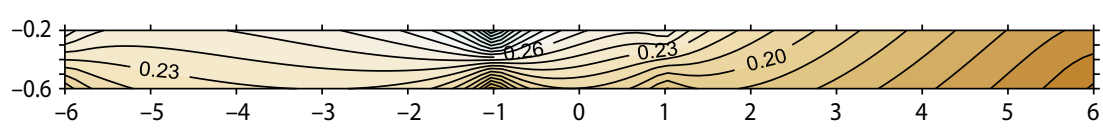

B
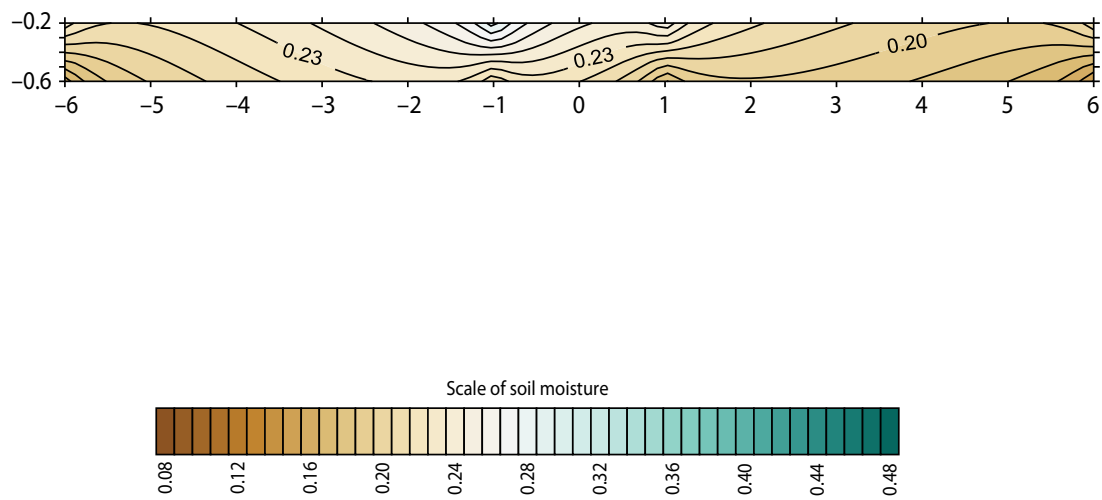

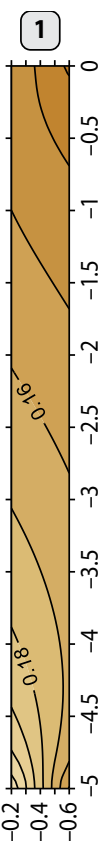

2

3
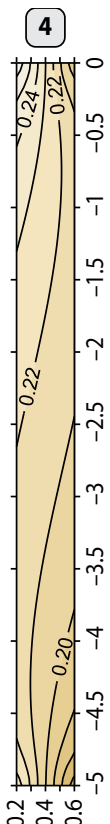

Figure 3. Soil moisture distribution in vertical plains in the lines A and B and in the positions $4 \div 1$. Facility W4, measurement session III 
G

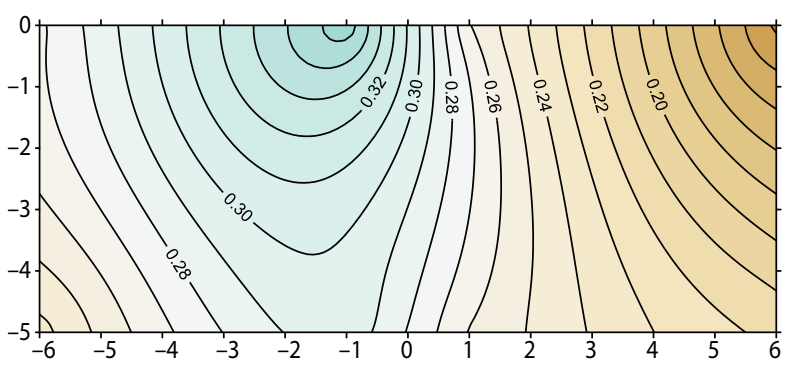

(D)

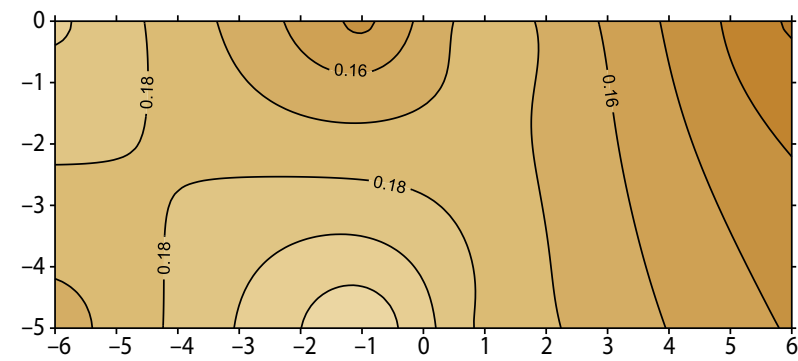

Scale of soil moisture

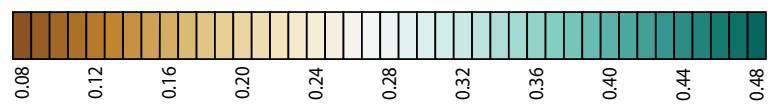

Figure 4. Soil moisture distribution in the terrain gradient plains at the depth $g$ and d. Facility W4, measurement session III

All the graphs were prepared according to the same scale of soil moisture. Surfer 9.2.397 by Golden Software Inc. was used for drawing isolines as well as 'Kriging' internal interpolation function.

In the example presented above (Fig. 3 and 4), there is a few percent difference in soil moisture in the positions close to the water run-off line along the slope at the same levels and several percent difference between levels. The height of these differences, at a low slope gradient, observed soil conditions and soil 'reinforcement' with root systems of local plants, is not a factor which is likely to activate the downflow of soil mass on the slope.

The objective of the statistical analysis of the material collected (Tadeusiewicz et al. 1993; Stanisz 2007) was to test a hypothesis that the spatial distribution of soil moisture behind the outlet of devices dehydrating forest slope roads depends on the localisation of a par- ticular place of moisture measurement in relation to the device outlet, including but not limited to:

- line of water run-off from a dehydrating device (position),

- roadway edge (sideway) (line),

- depth in the profile (level).

\section{SUMMARY AND CONCLUSIONS}

To summarize, the tests and analyses carried out, despite selecting the test facilities in the terrain of comparable properties (at the same slope road, at similar altitudes, with similar grain composition of soils), it was not possible to obtain a clear image and a full explanation of the observed spatial distribution of soil moisture in the area located behind the outlet of devices dehydrating forest roads. The scope of the works and tests carried out comprised only the most important properties of terrains, soils and facilities, which are relatively easy to be measured.

The analyses carried out, at a considerably high diversity in precipitation amounts, before measurement sessions, demonstrated that soil moisture values in sessions without dividing into respective facilities differ significantly (Tab. 5). It is a situation not corresponding to the measured precipitation sums: the highest moisture values were obtained in session III - with the lowest precipitation sums, and the lowest moisture values were obtained in session II, with the highest precipitation sums. It can be observed for $24 \mathrm{~h}$ precipitation sums from one, two and three days preceding the moisture measurement. Probably, there were differences in the local precipitation distribution (the station is located about $10 \mathrm{~km}$ from the test areas). Considering the system of average moisture values in the facilities, in relation to each measurement session (different sum of precipitation preceding sessions), a similar situation can be observed, with the exception of facility W2, where the highest moisture value was determined in session I, and the lowest one in session II.

Moisture diversity in the test facilities in each session, individually, is similar (Gołąb and Urban 2016); the highest moisture values were determined in facility W2 in sessions I and II, and in session III in facility $\mathrm{W} 1$; the lowest ones were determined in facility W4 in all measurement sessions (Tab. 2). The statistical tests 
Table 5. Results of testing zero hypotheses

\begin{tabular}{|c|c|c|c|c|c|c|c|}
\hline \multirow{2}{*}{$\begin{array}{l}\text { Tested variable } \\
\text { null hypothesis }\end{array}$} & \multirow{2}{*}{ Series } & Effect (Ef) & \multirow{2}{*}{ SS } & \multirow{2}{*}{$\mathrm{df}$} & \multirow{2}{*}{ MS } & \multirow{2}{*}{$\begin{array}{l}\mathrm{F} \\
\mathrm{p}\end{array}$} & \multirow{2}{*}{ Inference } \\
\hline & & Error (Err) & & & & & \\
\hline 1 & 2 & 3 & 4 & 5 & 6 & 7 & 8 \\
\hline \multirow{2}{*}{$\begin{array}{l}\text { Session } \\
\mathbf{H}_{0}: \mathrm{m}_{1}=\mathrm{m}_{2}=\mathrm{m}_{3}\end{array}$} & \multirow{2}{*}{$\mathrm{I} \div \mathrm{III}$} & Ef & 0.073590 & 2 & 0.036795 & \multirow{2}{*}{$\begin{array}{r}6.289427 \\
* 0.002268\end{array}$} & \multirow{2}{*}{ reject to $\mathrm{H}_{0}$} \\
\hline & & Err & 1.105707 & 189 & 0.005850 & & \\
\hline \multirow{6}{*}{$\begin{array}{l}\text { Facility } \\
\mathbf{H}_{\mathbf{0}}: \mathrm{m}_{1}=\mathrm{m}_{2}=\mathrm{m}_{3}=\mathrm{m}_{4}\end{array}$} & \multirow{2}{*}{ I } & Ef & 0.087340 & 3 & 0.029113 & \multirow{2}{*}{$\begin{array}{r}6.762997 \\
* 0.000527\end{array}$} & \multirow{2}{*}{ reject to $\mathrm{H}_{0}$} \\
\hline & & Err & 0.258287 & 60 & 0.004305 & & \\
\hline & \multirow{2}{*}{ II } & Ef & 0.087983 & 3 & 0.029328 & \multirow{2}{*}{$\begin{array}{r}6.803061 \\
* 0.000505\end{array}$} & \multirow{2}{*}{ reject to $\mathrm{H}_{0}$} \\
\hline & & Err & 0.258657 & 60 & 0.004311 & & \\
\hline & \multirow{2}{*}{ III } & Ef & 0.070378 & 3 & 0.023459 & \multirow{2}{*}{$\begin{array}{r}4.102952 \\
* 0.010269\end{array}$} & \multirow{2}{*}{ reject to $\mathrm{H}_{0}$} \\
\hline & & Err & 0.343063 & 60 & 0.005718 & & \\
\hline \multirow{6}{*}{$\begin{array}{l}\text { Line } \\
\mathbf{H}_{\mathbf{0}}: \mathrm{m}_{1}=\mathrm{m}_{2}\end{array}$} & \multirow{2}{*}{ I } & Ef & 0.000699 & 1 & 0.000699 & \multirow{2}{*}{$\begin{array}{l}0.125673 \\
0.724164\end{array}$} & \multirow{2}{*}{$\begin{array}{l}\text { there is no reason } \\
\text { to reject } \mathrm{H}_{0}\end{array}$} \\
\hline & & Err & 0.344927 & 62 & 0.005563 & & \\
\hline & \multirow{2}{*}{ II } & Ef & 0.001508 & 1 & 0.001508 & \multirow{2}{*}{$\begin{array}{l}0.270880 \\
0.604596\end{array}$} & \multirow{2}{*}{$\begin{array}{l}\text { there is no reason } \\
\text { to reject } \mathrm{H}_{0}\end{array}$} \\
\hline & & Err & 0.345132 & 62 & 0.005567 & & \\
\hline & \multirow{2}{*}{ III } & Ef & 0.006300 & 1 & 0.006300 & \multirow{2}{*}{$\begin{array}{l}0.959328 \\
0.331163\end{array}$} & \multirow{2}{*}{$\begin{array}{l}\text { there is no reason } \\
\text { to reject } \mathrm{H}_{0}\end{array}$} \\
\hline & & Err & 0.407141 & 62 & 0.006567 & & \\
\hline & I & Ef & 0.007221 & 3 & 0.002407 & 0.426762 & there is no reason \\
\hline & 1 & Err & 0.338406 & 60 & 0.005640 & 0.734534 & to reject $\mathrm{H}_{0}$ \\
\hline Position & 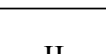 & Ef & 0.014618 & 3 & 0.004873 & 0.880553 & there is no reason \\
\hline $\mathbf{H}_{\mathbf{0}}: \mathrm{m}_{1}=\mathrm{m}_{2}=\mathrm{m}_{3}=\mathrm{m}_{4}$ & II & Err & 0.332022 & 60 & 0.005534 & 0.456355 & to reject $\mathrm{H}_{0}$ \\
\hline & WI & Ef & 0.032861 & 3 & 0.010954 & 1.726875 & there is no reason \\
\hline & III & Err & 0.380580 & 60 & 0.006343 & 0.171074 & to reject $\mathrm{H}_{0}$ \\
\hline & & Ef & 0.129013 & 1 & 0.129013 & 36.92651 & \\
\hline & 1 & Err & 0.216614 & 62 & 0.003494 & $* 0.000000$ & reject to $\mathrm{H}_{0}$ \\
\hline Level & 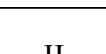 & Ef & 0.114814 & 1 & 0.114814 & 30.70611 & \\
\hline $\mathbf{H}_{0}: \mathrm{m}_{1}=\mathrm{m}_{2}$ & II & Err & 0.231826 & 62 & 0.003739 & $* 0.000001$ & reject to $\mathrm{H}_{0}$ \\
\hline & & Ef & 0.122219 & 1 & 0.122219 & 26.01986 & \\
\hline & III & Err & 0.291222 & 62 & 0.004697 & $* 0.000003$ & reject to $\mathrm{H}_{0}$ \\
\hline
\end{tabular}

Statistical significance $\mathrm{p}<0.05 ;{ }^{*}$ - statistically significant differences.

carried out demonstrated the significance of differences in moisture values in facility $\mathrm{W} 1$ and moisture values in facility W3 and W4, a similar significance of differences was obtained in session II but with the absence of variance homogeneity; in session III, the significance of differences was determined for facility $\mathrm{W} 1$ and $\mathrm{W} 4$ (Gołąb and Urban 2016).

The statistical analysis does not demonstrate any significant difference in moisture between soil samples arranged in lines A and B in any measurement session (Tab. 5), although the numbers (Gołąb and Urban 2016) are varied. In general, the soil in line A has higher moisture values but with distribution into respective sessions, this rule is not proved (Gołąb and Urban 2016).

It is similar for the marked positions (1, 2, 3 and 4), although moisture values differ among one another (Gołąb and Urban 2016) and the following rule may be observed: soils with highest moisture values in the position 2 and 3, soils with the lowest moisture values in the position 1 and 4, the statistical analysis does not demonstrate any significance in differences in any measurement session (Tab. 5). 
Significant differences in moisture of the samples tested was demonstrated in the analysis of the indicated top and bottom layer (Tab. 5). Higher moisture was discovered in top layers in all measurement sessions, with similar dynamics of changes in such layers (Gołąb and Urban 2016).

Generally, moisture changes in the observed area, usually few and several percent, are significant enough to plastify or fluidise the soil on the slope and lead to instability. Soil fluidisation takes place when a plasticity rate, which is a difference between the fluidity limit and plasticity limit, has a value ranging $1 \div 10 \%$ (for sandy dust and dust - soils classified as low-compacted) (Wiłun 2013). A factor hindering slope activation is the high content of soil structure, presence of tree roots, as well as low gradient of the slopes observed. A crucial factor reducing an erosion risk is the layer of an organic overburden, which buffers absorption through water soil profile flowing from dehydrating devices.

Comparing the results of the tests presented (Beskid Saqdecki) with the tests of the same type, conducted as per the same methodology in the year 2014 in Gorce (Gołą et al. 2016), it may be noted that the average soil moisture values in measurement sessions are slightly higher in Gorce than in Beskid Sądecki. It may be caused by the soil grain composition (Gorce - clay, B. Sądecki - dusty forms), it is observed despite higher terrain gradients and considerably lower precipitation sums before measurement sessions in Gorce.

There is the majority of average soil moisture values for the facilities in Gorce compared to the facilities in Beskid Sądecki, although moisture dynamics is higher in the soils near the facilities in Beskid Sądecki. This is also supported by differences in the soil particle size.

Soil moisture content in lines is comparable in both terrains, with slight dominance of moisture dynamics near Krynica facilities. There is a similar dependence for moisture and its dynamics in the positions for both terrains. Higher diversity of these systems (particularly in the division into lines 2 and 3 in relation to line 1 and 4) is more noticeable in Krynica tests, which may be explained by slightly better hydraulic conductivity properties in Krynica and higher terrain gradients in Gorce. In Krynica, better water absorption is possible through a soil profile and in Gorce, behind the outlet of devices, there is a run-off process observed. It can also explain the differences in moisture dynamics in layers - higher diversity is noticeable near Gorce facilities.

To conclude, it must be stated that the existing interpretation difficulties are connected with the multiplicity of factors and terrain conditions that affect the observed moisture distribution. Therefore, these tests must be regarded as an initiative for further works describing this issue. It is necessary to differentiate terrains where subsequent tests will be carried out (terrains with various gradients, with more permeable soils, in varied climatic conditions). The analysis ought to include more detailed soil tests, in particular, defining the limits of texture and shear strength in such soils. It is also recommended to measure the amount of water flowing from devices onto the slope. Extending the testing scope will be possible after obtaining funds at an appropriate level.

The following was discovered in the research:

- In the observed terrain conditions, at relatively low slope gradients and considerably limited soil hydraulic conductivity, water flows from dehydrating devices inside the soil, without significant differentiation in humidity in 'positions';

- The observed statistical significance in moisture difference at determined depths in all measurement sessions, at higher moisture values in the top layer, indicates a stronger tendency of precipitation water run-off in sub-surface layers, which results from poor hydraulic conductivity properties in local soils and a slope gradient,

- Relatively low moisture fluctuations on the slope (Tab. 5 in: Gołąb et al. 2016); maximally observed differences in the means for the facilities; from $2.56 \%$ to $7.22 \%$, maximally observed differences in the means for the position 3; from $3.44 \%$ to $9.31 \%$, insignificant terrain gradients and estimated very high share of coarse gravel and stone, which fulfils the role of a mechanical stabiliser for earth parts of the soil profile that do not create good conditions for landslides;

- Moisture differences in the lines and in the positions (Tab. 5 in: Gołąb et al. 2016) exist and indicate certain regularities but of no statistical significance;

- There is also no tendency for erosive damage of a linear type in the area examined. 


\section{Acknowledgements}

This research was financed by the Department of Forest Engineering University of Agriculture in Kraków.

\section{References}

Bardel T. 2012. O antropogenicznych przyczynach powstania osuwiska na zboczu byłej kopalni iłów „Kantoria” w Tarnowie. Górnictwo i geologia 7 (2), $35-47$.

Burzyński S., Rajsman M. 2006. Zasadnicze czynniki decydujące o parametrach dróg leśnych i obiektów towarzyszących. In.: Drogi leśne. Poradnik techniczny. Wydawnictwo Ośrodek Rozwojowo-Wdrożeniowy LP w Bedoniu, 30-33.

Characteristics of the Experimental Forestry Unit University of Agriculture in Kraków. http://lzdkrynica. ur.krakow.pl/charakterystyka.html. Accessed 29 September 2015.

Gołąb J. 2011. Natężenie powierzchniowego spływu wody z leśnej drogi stokowej. Infrastruktura i Ekologia Terenów Wiejskich, 7, 199-208.

Gołąb J. 2012. Symulacja objętości powierzchniowego spływu wody z sieci dróg leśnych w terenie górskim. Infrastruktura i Ekologia Terenów Wiejskich, 2/III, 129-139.

Gołąb J., Badach E., Słowik-Opoka E. 2016. Przestrzenny rozkład wilgotności gruntu w obszarze przyległym do wylotu urządzeń odwadniających drogi leśne. Sylwan, 160 (10), 806-815.

Gołąb J., Kormanek M. 2013. The characteristics of selected design factors of forest roads and their use influencing their functional advantages in the mountains. Prace Komisji Nauk Rolniczych, Leśnych i Weterynaryjnych PAU, 18, 87-99.
Gołąb J., Urban K. 2016. Uwilgotnienie gruntu w obszarze za wylotem urządzeń odwadniających leśne drogi stokowe. Sprawozdanie z badań wykonanych na terenie Leśnego Zakładu Doświadczalnego UR w Krakowie, unpublished.

Gołąb J., Wańczyk R., Matusiak B. 2006. Surface runoff from slanting forest roads. Acta Scietiarum Polonorum Silvarum Colendarum Ratio et Industria Lignaria, 5 (1), 13-25.

Kondracki J. 2011. Geografia regionalna Polski. Wyd. 3 - uzupełnione. Wydawnictwo Naukowe PWN, Warszawa.

PN-86/B-02480. Grunty Budowlane. Określenia, symbole, podział i opis gruntów.

PN-ISO 11465:1999. Jakość gleby - Oznaczanie zawartości suchej masy gleby i wody w glebie w przeliczeniu na suchą masę gleby - Metoda wagowa.

Stanisz A. 2007. Przystępny kurs statystyki z zastosowaniem STATISTICA PL na przykładach z medycyny. Tom 2. Statsoft Polska, Kraków.

Stypuła K. 1977. Mechanika gruntów z gruntoznawstwem drogowym. Wydawnictwo Akademii Rolniczej w Krakowie, Kraków.

Tadeusiewicz R., Izworski A., Majewski J. 1993. Biometria. Wydawnictwo AGH, Kraków.

Twardowski K., Drożdżak R. 2006. Pośrednie metody oceny właściwości filtracyjnych gruntów. Wiertnictwo. Nafta. Gaz, 23 (1), 477-486.

Wemple B.C., Jones J.A. 2003. Runoff production on forest roads in a steep, mountain catchment. Water Resources Research, 39 (8), 1220. DOI: 10.1029/2002WR001744.

Wiłun Z. 2013. Zarys geotechniki. Wydawnictwo Komunikacji i Łączności, Warszawa.

Zydroń T., Cholewa M. 2014. Analiza stateczności pokryw stokowych na przykładzie zbocza z okolic Siar k. Gorlic. Infrastruktura i Ekologia Terenów Wiejskich, 1 (1), 73-87. 